\title{
ANALISIS KEMAMPUAN PEMECAHAN MASALAH MATEMATIK PADA MATERI LINGKARAN SISWA SMP KELAS VIII
}

\author{
Diah Kurniawati ${ }^{1}$, Euis Eti Rohaeti ${ }^{2}$, M. Afrilianto $^{3}$ \\ 1,2,3 IKIP Siliwangi, Jl. Terusan Jenderal Sudirman, Cimahi, Jawa Barat, Indonesia \\ ${ }^{1}$ diahkurniawati37@gmail.com, ${ }^{2}$ e2rht@yahoo.com \\ ${ }^{3}$ muhammadafrilianto1@ikipsiliwangi.ac.id
}

\begin{abstract}
The Purpose of descriptive qualitative research to describe the problem-solving ability of student mathematics on the material circle for student class VIII SMP in Karawang. The subject of this study consisted of 6 selected students. Data collection techniques using the test. The result of data analysis showed the students beginning ability were included in the low category, because of only about $59 \%$ of students from 6 people who are able to solve mathematical problems in the material of the circle.
\end{abstract}

Keywords: Mathematical Problem Solving

\begin{abstract}
Abstrak
Penelitian deskriptif kualitatif ini bertujuan untuk mendeskripsikan kemampuan pemecahan masalah matematik siswa pada materi lingkaran bagi siswa kelas VIII SMP dengan memanfaatkan pendekatan deduktif. Subjek penelitian ini terdiri dari 6 siswa yang dipilih. Teknik pengumpulan data menggunakan teknik tes. Hasil analisis data menunjukkan bahwa kemampuan awal siswa tergolong dalam kelompok rendah, karena hanya sekitar 59\% siswa dari 6 orang yang mampu menyelesaikan permasalahan matematika pada materi lingkaran tersebut.
\end{abstract}

Kata Kunci: Kemampuan Pemecahan Masalah Matematik

How to cite: Kurniawati, D., Rohaeti, E.E., \& Afrilianto, M., (2018). Analisis Kemampuan Pemecahan Masalah Matematik pada Materi Lingkaran Siswa SMP Kelas VIII. JPMI - Jurnal Pembelajaran Matematika Inovatif, 1 (4), 725-734.

\section{PENDAHULUAN}

Kemampuan pemecahan masalah memiliki peranan yang sangat penting dalam berbagai bidang ilmu khususnya dalam mata pelajaran matematika karena dapat melatih siswa untuk berpikir dalam memecahkan masalah serta dapat meningkatkan aktivitas belajar siswa, oleh karena itu kemampuan pemecahan masalah matematik harus dimiliki oleh setiap peserta didik. Sebenarnya, ketika peserta didik sedang dihadapkan pada masalah, maka mereka akan menemukan sesuatu yang baru yang dapat mengembangkan pengetahuannya. Hal ini depertegas oleh pernyataan (Mulyasa, 2013) yang mengatakan, "kalau peserta didik dihadapkan pada suatu masalah, pada akhirnya mereka bukan hanya sekedar memecahkan masalah, tetapi juga belajar sesuatu yang baru".

Pemecahan masalah merupakan tujuan umum dalam pembelajaran matematika, bahkan sebagai jantungnya matematika artinya kemampuan pemecahan masalah merupakan kemampuan dasar dalam belajar matematika. Pemecahan masalah matematika merupakan tahapan yang harus dilalui mahasiswa dalam menyelesaikan suatu persoalan yang dihadapainya. Menurut (Hendriana \& Soemarmo, 2014) solusi soal pemecahan masalah 
memuat empat langkah penyelesaiannya yaitu memahami masalah, merencanakan masalah, menyelesaikan masalah sesuai rencana dan melakukan pengecekan kembali terhadap semua langkah yang dikerjakan.

Banyak ahli yang mengungkapkan pentingnya belajar dalam memecahkan masalah matematika. Hidayat \& Sariningsih (2018) mengemukakan bahwa dalam pembelajaran matematika pemecahan masalah merupakan inti pembelajaran yang merupakan kemampuan dasar dalam proses pembelajaran. Untuk meningkatkan kemampuan memecahkan masalah perlu dikembangkan keterampilan memahami masalah, membuat model matematika, menyelesaikan masalah dan menafsirkan solusinya.

Proses pemecahan masalah matematik merupakan salah satu kemampuan dasar matematik yang harus dikuasi siswa sekolah menengah. Pentingnya pemilikan kemampuan tersebut tercermin dari pernyatan (Hendriana \& Soemarmo, 2014) bahwa pemecahan masalah matematik merupakan salah satu tujuan penting dalam pembelajran matematika bahkan proses pemecahan masalah matemtik merupakan jantungnya matematika. Pendapat tersebut sejalan dengan tujuan pembelajaran matematika dalam KTSP (2006). Tujuan tersebut antara lain: menyelesaikan masalah, berkomunikasi menggunakan simbol matematik, table diagram, dan lainnya; menghargai kegunaan matematika dalam kehidupan sehari-hari, memiliki rasa tahu perhatian, minat belajar matematika, serta memiliki sikap teliti dan konsep diri dalam menyelesaikan masalah.

Demikian pula pentingnya pemilikan kemampuan pemecahan masalah sejalan dengan pendapat beberapa pakar. (Hendriana, 2002) mengemukakan bahwa pemilikan kemampuan pemecahan masalah membantu siswa berpikir analitik dalam mengambil keputusan dalam kehidupan sehari-hari dan membantu meningkatkan kemampuan berpikir kritis dalam menghadapi situasi baru. Banyak ahli yang mengungkapkan pentingnya belajar dalam memecahkan masalah matematika. (Mulyasa, 2013) mengatakan bahwa "proses pemecahan masalah memberikan kesempatan peserta didik berperan aktif dalam mempelajari, mencari, dan menemukan sendiri informasi/data untuk diolah menjadi konsep, prinsip, teori, atau kesimpulan".

\section{METODE}

Jenis penelitian ini adalah penelitian deskriptif kualitatif yang bertujuan untuk menggambarkan secara sistematis mengenai kemampuan pemecahan masalah matematik pada materi lingkaran bagi siswa kelas VIII. Subjek penelitian ini adalah 6 orang siswa kelas VIII SMP di Karawang yang diambil dengan teknik pengambilan sampel berdasarkan pertimbangan tertentu. Tempat penelitian ini berada di salah satu SMP di daerah Karawang yang beralamat di Jalan Manunggal VII Palumbon Sari, Kel. Palumbon Sari, Kec. Karawang Timur, Kab. Karawang. Waktu yang diberikan untuk mengerjakan 5 soal adalah 2 jam pelajaran yaitu $2 \times 40$ menit. Teknik pengumpulan data untuk mendapatkan data yang relevan dalam penelitian ini menggunakan metode tes. Bentuk tes yang digunakan adalah tes uraian (tes essay).

\section{HASIL DAN PEMBAHASAN}

\section{Hasil}

Hasil skor jawaban siswa sebanyak 5 butir soal yang telah di ujicobakan kepada 6 orang siswa yaitu sebagai berikut: 
Tabel 1 . Deskripsi Kemampuan Pemecahan Masalah Matematik Siswa dalam Memahami Masalah pada soal nomor 1

\begin{tabular}{cc}
\hline Kode Siswa & Jumlah Score \\
\hline 001 & 4 \\
002 & 3 \\
003 & 3 \\
004 & 3 \\
005 & 2 \\
006 & 1 \\
\hline Jumlah & 16 \\
\hline Presentase (\%) & $66.7 \%$ \\
\hline
\end{tabular}

Kemampuan pemecahan masalah matematik siswa dalam memahami masalah yang telah dipelajari pada soal 1 dengan presentase $66.7 \%$.

Tabel 2. Deskripsi Kemampuan Pemecahan Masalah Matematik Siswa dalam Merencanakan atau Merancang Strategi Pemecahan Masalah pada soal nomor 2

\begin{tabular}{cc}
\hline Kode Siswa & Jumlah Score \\
\hline 001 & 2 \\
002 & 4 \\
003 & 3 \\
004 & 2 \\
005 & 1 \\
006 & 2 \\
\hline Jumlah & 14 \\
\hline Presentase (\%) & $58.3 \%$ \\
\hline
\end{tabular}

Kemampuan pemecahan masalah matematik siswa dalam merencanakan atau merancang strategi pemecahan masalah yang telah dipelajari pada soal 2 dengan presentase $58.3 \%$.

Tabel 3. Deskripsi Kemampuan Pemecahan Masalah Matematik Siswa dalam Melaksanakan Perhitungan pada soal nomor 3

\begin{tabular}{cc}
\hline Kode Siswa & Jumlah Score \\
\hline 001 & 3 \\
002 & 3 \\
003 & 3 \\
004 & 2 \\
005 & 2 \\
006 & 1 \\
\hline Jumlah & 14 \\
\hline Presentase (\%) & $58.3 \%$ \\
\hline
\end{tabular}

Kemampuan pemecahan masalah matematik siswa dalam melaksanakan perhitungan yang telah dipelajari pada soal 3 dengan presentase $58.3 \%$. 
Tabel 4. Deskripsi Kemampuan Pemecahan Masalah Matematik Siswa dalam Melaksanakan Perhitungan pada soal nomor 4

\begin{tabular}{cc}
\hline Kode Siswa & Jumlah Score \\
\hline 001 & 3 \\
002 & 2 \\
003 & 3 \\
004 & 3 \\
005 & 1 \\
006 & 1 \\
\hline Jumlah & 13 \\
\hline Presentase (\%) & $54.2 \%$ \\
\hline
\end{tabular}

Kemampuan pemecahan masalah matematik siswa dalam melaksanakan perhitungan yang telah dipelajari pada soal 4 dengan presentase $54.2 \%$.

Tabel 5. Deskripsi Kemampuan Pemecahan Masalah Matematik Siswa dalam Memeriksa Kembali Kebenaran Hasil Atau Solusi pada soal nomor 5

\begin{tabular}{cc}
\hline Kode Siswa & Jumlah Score \\
\hline 001 & 3 \\
002 & 3 \\
003 & 3 \\
004 & 2 \\
005 & 1 \\
006 & 2 \\
\hline Jumlah & 14 \\
\hline Presentase $(\%)$ & $58.3 \%$ \\
\hline
\end{tabular}

Kemampuan pemecahan masalah matematik siswa dalam memeriksa kembali kebenaran hasil atau solusi yang telah dipelajari pada soal 5 dengan presentase $58.3 \%$.

\section{Pembahasan}

Menurut (Hidayat \& Sariningsih, 2018) Pemecahan masalah memuat empat langkah penyelesaiannya yaitu memahami masalah, merencanakan masalah, menyelesaikan masalah sesuai rencana dan melakukan pengecekan kembali terhadap semua langkah yang dikerjakan.

\section{Pembahasan soal untuk no. 1.}

Di pusat sebuah kota rencananya akan dibuat sebuah taman berbentuk lingkaran dengan diameter $56 \mathrm{~m}$. Di dalam taman itu akan dibuat kolam berbentuk lingkaran berdiameter $28 \mathrm{~m}$. Jika diluar kolam akan ditanami rumput dengan biaya Rp. $6.000 .000,-/ \mathrm{m}^{2}$, hitunglah seluruh biaya yang harus dikeluarkan untuk menanam rumput tersebut.

Indikator Silabus : Menghitung keliling dan luas lingkaran 


\section{Analisis jawaban :}
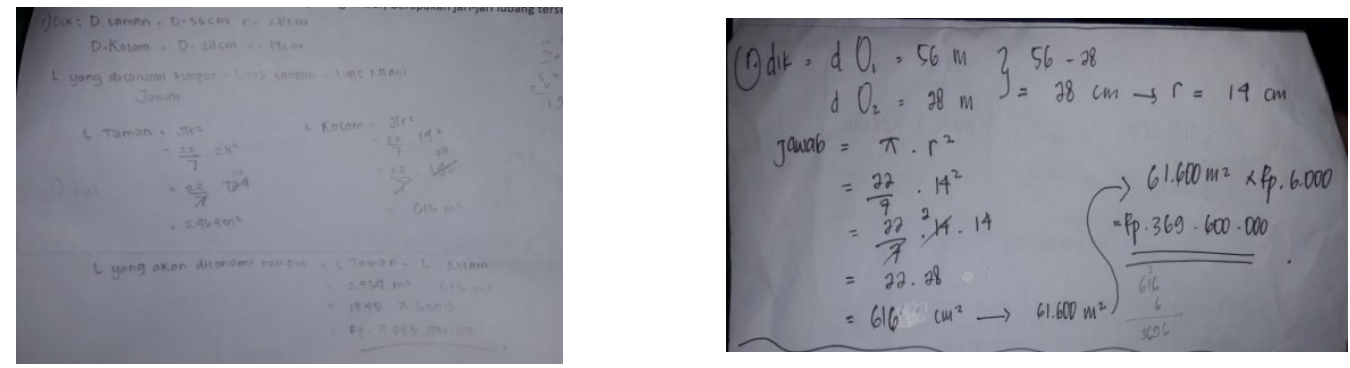

Gambar 1. Jawaban benar siswa pada subjek 2 Gambar 2. Jawaban salah siswa pada subjek 3

Analisis dari jawaban siswa yang benar pada gambar 1 adalah:

1. Siswa sudah memahami masalah mengenai data yang tersedia, dan apa yang ditanyakan.

2. Siswa sudah mampu menerapkan indikator dalam menyelesaikan masalah pada soal tersebut.

3. Siswa sudah mampu meyelesaikan soal tersebut berdasarkan strategi pemecahan masalah yang sudah di tentukan pada point 2.

4. Siswa sudah mampu untuk memeriksa kebenaran setiap langkahnya.

Analisis dari jawaban siswa yang salah pada gambar 2 adalah:

1. Siswa tidak memahami konsep dan maslah yang terdapat pada soal tersebut sehingga jawaban siswa salah karena tidak mengtahui unsur-unsur apa saja yang terdapat pada soal tersebut.

2. Siswa tidak mampu menerapkan indikator pemecahan masalah

3. dalam menyelesaikan masalah pada soal tersebut.

Pembahasan soal untuk no. 2

Sebuah ban sepeda memiliki jari-jari sebanyak 44 dan masing-masing berjarak $4 \mathrm{~cm}$. hitunglah panjang jari-jari ban sepeda jika $\quad \pi=\frac{22}{7}$ dan tentukan panjang lintasan yang dilalui
ban sepeda bila berputar 1000 kali.

Indikator Silabus : Menghitung keliling dan luas lingkaran

\section{Analisis jawaban :}
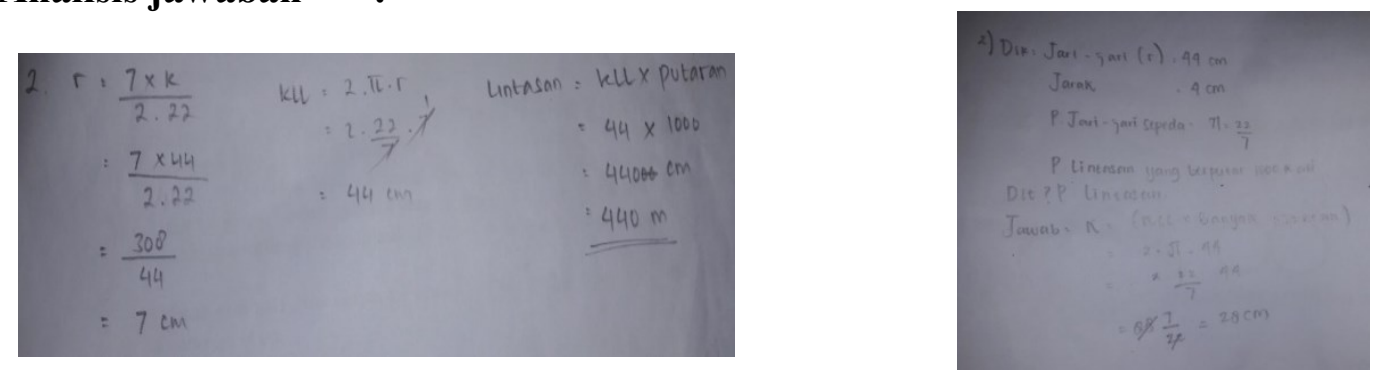

Gambar 3. Jawaban benar siswa pada subjek 4 Gambar 4. Jawaban salah siswa pada subjek 2

Analisis dari jawaban siswa yang benar pada gambar 3 adalah:

1. Siswa sudah memahami masalah mengenai data yang tersedia, dan apa saja yang ditanyakan.

2. Siswa sudah mampu menerapkan indikator dan rumus apa saja yang digunakan dalam menyelesaikan masalah pada soal tersebut. 
3. Siswa sudah mampu mencari nilai $r$ dan menentukan panjang lintasan dalam meyelesaikan soal tersebut berdasarkan strategi yang sudah di tentukan pada point 2 .

4. Siswa sudah mampu untuk memeriksa bahwa langkah yang dipilih sudah benar.

Analisis dari jawaban siswa yang salah pada gambar 4 adalah:

1. Siswa tidak mampu memahami masalah dan unsur-unsur apa saja yang ada pada soal tersebut, sehingga jawaban siswa tersebut salah.

2. Siswa tidak mampu merencanakan atau merancang strategi pemecahan masalah pada soal tersebut.

\section{Pembahasan soal untuk no. 3}

Jika diameter pipa adalah $28 \mathrm{~cm}$ dan panjang permukaan air adalah $26 \mathrm{~cm}$, berapakah luas penampang air itu?

Indikator Silabus : Menggunakan hubungan sudut pusat, panjang busur, luas juring dalam pemecahan masalah

\section{Analisis jawaban :}

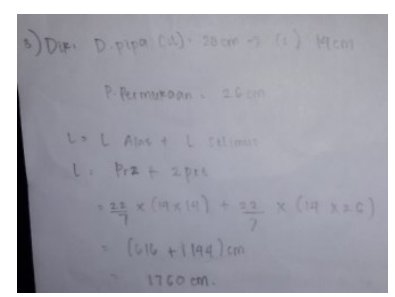

Gambar 5. Jawaban benar siswa pada subjek 2 Gambar 6 Jawaban salah siswa pada subyek 3

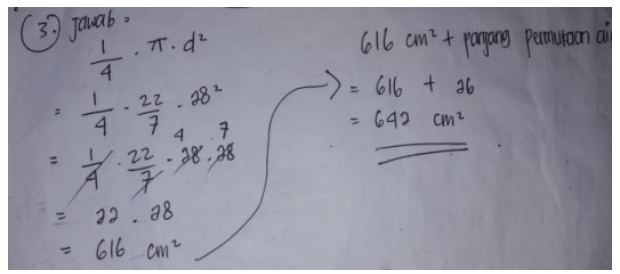

Analisis dari jawaban siswa yang benar pada gambar 5 adalah:

1. Siswa sudah mampu memahami masalah mengenai data yang tersedia, dengan cara menuliskan apa yang sudah diketahui dan ditanyakan secara benar.

2. Langkah selanjutnya siswa sudah mampu menentukan dan merencanakan rumus atau strategi apa yang digunakan untuk menyelesaikan masalah pada soal tersebut.

3. Pada langkah ini siswa sudah mampu menyelesaikan perhitungan mengenai masalah pada soal tersebut berdasarkan strategi yang sudah di rencanakan pada point 2 .

4. Pada langkah selanjutnya siswa tidak melakukan langkah terakhir yaitu memeriksa kembali hasil perhitungan, karena berdasarkan dari wawancara siswa tersebut tidak mengetahui cara membuktikan perhitungannya sudah benar atau masih ada kesalahan.

Analisis dari jawaban siswa yang salah pada gambar 6 adalah:

1. Siswa tidak mampu memahami dan menuliskan unsur-unsur apa saja yang ada pada soal tersebut, sehingga jawaban siswa tersebut salah.

2. Siswa tidak mampu merencanakan atau merancang strategi (menggunakan rumus apa) dalam pemecahan masalah pada soal tersebut.

\section{Pembahasan soal untuk no. 4}

Dua buah lempeng alumunium yang berbentuk lingkaran dengan pusat di A dan B, masingmasing berjari-jari $34 \mathrm{~cm}$ dan $10 \mathrm{~cm}$. Kedua lempengan tersebut dimasukkan kedalam sebuah 
lubang berbentuk lancip. Jika jarak bagian lubang yang menyentuh kedua lempengan tersebut pada sisi yang sama adalah $32 \mathrm{~cm}$, maka gambarkanlah keadaan tersebut dan tentukanlah jarak titik pusat kedua lempengan tersebut.

Indikator Silabus : Menghitung panjang garis singgung persekutuan dua lingkaran

\section{Analisis jawaban :}

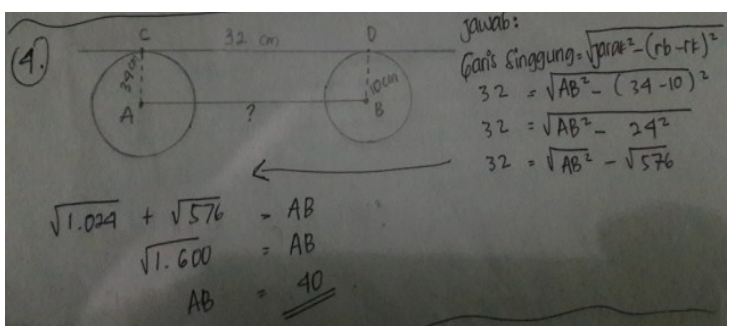

Gambar 7. Jawaban benar siswa pada subyek 3

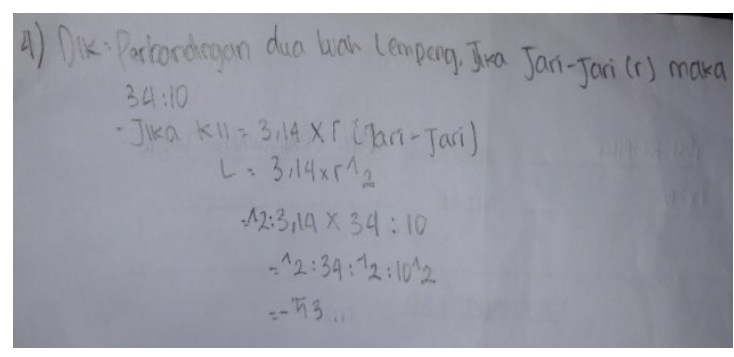

Gambar 8. Jawaban salah siswa pada subyek 6

Analisis dari jawaban siswa yang benar pada gambar 7 adalah:

1. Siswa sudah mampu memahami masalah mengenai data yang tersedia, dengan cara menggambar 2 lingkaran sesuai permasalahan pada soal tersebut.

2. Langkah selanjutnya siswa sudah mampu menentukan dan merencanakan rumus atau strategi apa yang digunakan untuk menyelesaikan masalah pada soal tersebut.

3. Pada langkah ini siswa sudah mampu menyelesaikan perhitungan mengenai masalah pada soal tersebut berdasarkan strategi yang sudah di rencanakan pada point 2 .

Analisis dari jawaban siswa yang salah pada gambar 8 adalah:

1. Siswa tidak mampu memahami masalah dan menuliskan unsur-unsur apa saja yang ada pada soal tersebut, sehingga jawaban siswa tersebut salah.

2. Siswa tidak mampu merencanakan atau merancang strategi (menggunakan rumus apa) dalam pemecahan masalah pada soal tersebut.

3. Pada langkah ini siswa sudah mampu melakukan perhitungan, tetapi terdapat kesalahan pada konsep. Sehingga jawabannya salah.

\section{Pembahasan soal untuk no. 5}

Delapan buah roda dililit dengan tali seperti gambar berikut, masing-masing roda diameternya $14 \mathrm{~cm}$.

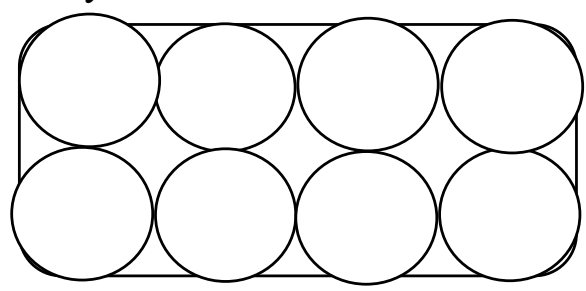

Indikator Silabus : Menghitung panjang garis singgung persekutuan dua lingkaran

\section{Analisis jawaban :}


Gambar 9. Jawaban benar siswa pada subyek 5 Gambar 10. Jawaban benar siswa pada subyek 1

Analisis dari jawaban siswa yang benar pada gambar 9 adalah:

1. Siswa sudah mampu memahami masalah mengenai data yang tersedia, dengan cara menggambar 2 lingkaran sesuai permasalahan pada soal tersebut.

2. Langkah selanjutnya siswa sudah mampu menentukan dan merencanakan rumus atau strategi apa yang digunakan untuk menyelesaikan masalah pada soal tersebut.

3. Pada langkah ini siswa sudah mampu menyelesaikan perhitungan mengenai masalah pada soal tersebut berdasarkan strategi yang sudah di rencanakan pada point 2.

4. Pada langkah selanjutnya siswa sudah mampu melakukan langkah terakhir yaitu memeriksa kembali hasil perhitungan, dengan cara mensubsitusi hasil garis singgung untuk mencari titik pusat kedua lempengan.

Analisis dari jawaban siswa yang salah pada gambar 10 adalah:

1. Siswa tidak mampu memahami masalah dan menuliskan unsur-unsur apa saja yang ada pada soal tersebut, sehingga jawaban siswa tersebut salah.

2. Siswa tidak mampu merencanakan atau merancang strategi (menggunakan rumus apa) dalam pemecahan masalah pada soal tersebut.

3. Pada langkah ini siswa sudah mampu melakukan perhitungan, tetapi terdapat kesalahan pada konsep. Sehingga jawabannya salah.

Dikarenakan rendahnya kemampuan pemecahan masalah matematis, diperlukan adanya perubahan dalam kegiatan pembelajaran, sehingga pembelajaran dapat berjalan lebih menyenangkan dan bermakna bagi siswa hal tersebut sejalan dengan pernyataan Monica, Afrilianto, \& Rohaeti, (2018). Sehingga jika kita menginginkan siswa belajar secara bermakna, pembelajaran yang kita sesuaikan harus disesuaikan dengan tahap berfikir siswa.

\section{KESIMPULAN}

Berdasarkan hasil penelitian dan pembahasan, maka dapat disimpulkan bahwa kemampuan pemecahan masalah matematik siswa kelas VIII SMP di Karawang dalam menyelesaikan permasalahan matematika pada materi lingkaran termasuk pada kategori rendah. Dari 6 subjek penelitian siswa yang mampu mengerjakan soal no 1 hanya 3 orang, no 2 hanya 1 orang, no 3 hanya 3 orang, no 4 hanya 3 orang, dan no 5 hanya 2 orang. Dapat disimpulkan hanya sekitar 59\% siswa dari 6 orang yang mampu menyelesaikan permasalahan matematika pada materi lingkaran tersebut. Langkah yang jarang dilakukan subjek dalam menyelesaikan permasalahan adalah memeriksa kembali. Alasan subjek tidak melakukan kegiatan ini dikarenakan tidak tahu cara membuktikan jawabannya benar atau salah atau lupa memeriksa jawabannya atau sudah merasa yakin dengan jawabannya. 
Pada penelitian ini, hanya mengkaji pemecahan masalah matematik saja, selanjutnya dapat dilakukan penelitian lanjutan untuk melihat pengaruh model pembelajaran yang disajikan guru dalam menyampaikan konsep pembelajaran mengenai lingkaran.

\section{DAFTAR PUSTAKA}

Hendriana, H. (2002). Meningkatkan Kemampuan, Pengajuan dan Pemecahan Masalah Matematika dengan Pembelajaran Berbalik Studi Eksperimen pada Siswa Kelas I SMU Negeri 23 Kota Bandung. Tesis pada Sekolah Pasca Sarjana UPI.: Tidak Diterbitkan.

Hendriana, H., \& Soemarmo, U. (2014). Penilaian Pembelajaran Matematika. Bandung: Refika Aditama.

Hidayat, W., \& Sariningsih, R. (2018). Kemampuan Pemecahan Masalah Matematis dan Adversity Quotient Siswa SMP Melalui Pembelajaran Open Ended. JNPM (Jurnal Nasional Pendidikan Matematika), 2(1), 109-118.

Monica, P. T., Afrilianto, M., \& Rohaeti, E. E. (2018). KEMAMPUAN PEMECAHAN MASALAH MATEMATIS SISWA SMP PADA MATERI PELUANG DENGAN PENDEKATAN KONTEKSTUAL. JPMI (Jurnal Pembelajaran Matematika Inovatif), 1(3), 219-228.

Mulyasa, E. (2013). Pengembangan dan implementasi kurikulum 2013. PT Remaja Rosdakarya. 
734 Kurniawati, Rohaeti, \& Afrilianto, Analisis Kemampuan Pemecahan Masalah Matematik... 